\title{
ANALISIS KINERJA KEUANGAN PERUSAHAAN DENGAN MENGGUNAKAN ALTMAN Z SCORE DAN PENGHARUHNYA TERHADAP HARGA SAHAM
}

\author{
Nadia Bella Salsabila * \\ Wahyudi** \\ Universitas Pembangunan Nasional Veteran Jakarta \\ *) nadiabella.salsabila@gmail.com,**)upnvj.wahyudi@gmail.com
}

\begin{abstract}
This research is a quantitative research that aims to analyze company's financial performance using Altman Z Score and also to determine the effect of the Altman Z Score variable on stock prices. The population in this study are consumer goods industry companies in 2016-2017 which are listed on the Indonesia Stock Exchange (IDX). The samples taken were 72 companies with purposive sampling method. The analysis technique used is Multiple Linear Regression Analysis with IBM SPSS 23 program and a significance level of 5\% (0.05). The results of this study indicate that (1) Z score of 72 samples of companies listed on the Indonesia Stock Exchange (IDX) in 2016-2017 Obtained 4 companies in the unhealthy category, 9 companies in the gray area category (unsound), and 59 companies in the healthy category (2) RETA, EBITA, and BVEBVTL variables affect stock prices while WCTA and Z Score variables do not affect stock prices.
\end{abstract}

Keywords: Altman Z Score, Stock Price

\section{PENDAHULUAN}

\subsection{Latar Belakang Penelitian}

Berdasarkan Laporan Analisis Perkembangan Industri 2017 oleh Kemenperin, industri manufaktur mengalami penurunan pada kontribusi dalam Produk Domestik Bruto dari sekitar 20,51\% pada tahun 2016 menjadi sebesar 20,16\% pada tahun 2017. Kualitas hasil produksi industri manufaktur Indonesia masih kalah jika dibandingkan dengan hasil produksi negara lain. Hal ini yang menyebabkan rendahnya nilai jual dan daya saing hasil produksi.

Mirae Asset Sekuritas Indonesia menilai bahwa pertumbuhan industri barang konsumsi yang ada di Indonesia sedang mengalami perlambatan dalam beberapa tahun terakhir. Terdapat beberapa faktor yang menjadi penyebab perlambatan pada sektor yang biasa disebut Fast Moving Consumer Good (FMCG) tersebut. Perlambatan tersebut tercermin dari kinerja beberapa emiten yang melantai di Bursa Efek Indonesia (BEI), seperti PT Unilever Indonesia Tbk (UNVR) yang kinerjanya anjlok hingga 19,7\%, PT CBP Sukses Makmur Tbk (ICBP) sahamnya tergelincir $3,57 \%$ dan PT Kalbe Farma Tbk (KLBF) juga merosot 20,23\%. (CNBC Indonesia,2018). Hal ini menunjukan kinerja industri barang konsumsi mengalami penurunan.

Sepanjang sembilan bulan pertama tahun 2017, tercatat tiga dari empat emiten terbesar di sub sektor makanan dan minuman dalam kategori industri barang konsumsi mencatatkan pelemahan pertumbuhan laba bersih. Keempat emiten tersebut adalah PT Indofood CBP Sukses Makmur Tbk (ICBP), PT Indofood Sukses Makmur Tbk (INDF), PT Mayora Indah Tbk (MYOR), dan PT Ultrajaya Milk Industry \& Trading Company Tbk (ULTJ). Hal ini menunjukkan bahwa tekanan terhadap daya beli masyarakat Indonesia belum usai. Kinerja saham barang konsumsi perlu diwaspadai, pasalnya ada kencenderungan ekspektasi terhadap penjualan ritel turun. Hal tersebut berpotensi mendorong kinerja emiten dari sektor barang konsumsi tertekan. Penjualan tertekan pada akhirnya berdampak pada kinerja keuangan emiten-emiten sektor barang konsumsi, termasuk yang berada pada sub sektor makanan dan minuman (CNBC, Indonesia). Hal ini menunjukan kinerja industri barang konsumsi mengalami penurunan dari sisi pertumbuhan laba. Bila perusahaan memiliki kinerja keuangan yang sehat berarti perusahaan dapat berkembang baik dan bila perusahaan dalam yang tidak sehat maka perlu diwaspadai karena berisiko tinggi dan

EQUITY: Jurnal Ekonomi, Manajemen, Akuntansi | Vol. 22, No. 1 175 DOI: 10.34209/equ.v22i1.924 
dapat memicu kebangkrutan. Untuk memastikan kinerja perusahaan sehat atau tidak sehat dapat dilihat dan diukur melalui analisis rasio keuangan terhadap laporan keuangan. Salah satu analisis rasio yang dapat digunakan adalah dengan menggunakan analisis Altman Z Score. Altman Z Score merupakan suatu model yang dapat digunakan untuk meramal atau memprediksi keuangan suatu perusahaan. Analisis dengan menggunakan Altman Z Score yaitu menghitungkan nilai dari beberapa rasio keuangan dan kemudian dimasukan dalam persamaan deskriminan. Menurut Sukmawati dkk (2014) Z Score dapat digunakan sebagai bahan untuk pertimbangan bagi investor dalam menganalisis perkembangan kinerja dan tingkat kesehatan perusahaan perusahaan emiten untuk menghindari terjadinya kesalahan investasi.

Berdasarkan fenomena, gap research, dan hasil penelitian terdahulu, peneliti tertarik melakukan penelitian dengan tema "Analisis Kinerja Keuangan Perusahaan dengan Menggunakan Altman Z Score Dan Pengaruhnya Terhadap Harga Saham (Studi Kasus Pada Perusahaan Industri Barang Konsumsi di Bursa Efek Indonesia Tahun 2016-2017)”

\section{TINJAUAN PUSTAKA DAN PENGEMBANGAN HIPOTESIS}

\subsection{Harga Saham dan Signalling Theory}

Berdasarkan Undang-Undang No. 8 tahun 1995 tentang pasar modal, saham merupakan surat berharga sebagai bukti pemilikan individu/institusi dalam suatu perusahaan (biasa dipegang perorangan/lembaga pada suatu perusahaan). Sedangkan harga saham berdasarkan UndangUndang No.8 tahun 1995 tentang pasar modal pada hakekatnya merupakan penerimaan besarnya pengorbanan yang harus dilakukan oleh setiap investor untuk penyertaan dalam perusahaan.

Harga saham suatu perusahaan merupakan salah satu bentuk informasi ataupun sinyal dalam rangka menarik investor untuk melakukan pembelian saham untuk menanamkan modalnya diperusahaan tersebut. Hal ini sejalan dengan Signaling Theory yang dikembangkan oleh Ross (1977) teori yang menjelaskan pentingnya pengukuran kinerja adalah teori signal (signaling theory). Menurut Brigham \& Houston (2011, hlm. 186) menyatakan bahwa 'teori sinyal adalah suatu tindakan yang diambil oleh manajemen suatu perusahaan memberikan petunjuk kepada investor tentang bagaimana manajemen menilai prospek perusahaan tersebut'.

Tanggapan para investor terhadap sinyal positif dan negatif sangat mempengaruhi kondisi pasar, investor akan bereaksi dengan berbagai cara dalam menanggapi sinyal tersebut, seperti memburu saham yang dijual atau melakukan tindakan dalam bentuk tidak bereaksi seperti "wait and see" atau tunggu dan lihat dulu berkembangan yang ada baru kemudian mengambil tindakan.

\subsection{Analisa Kinerja Keuangan, Altman Z Score, Harga Saham}

Menurut Fahmi (2008, hlm. 131) kinerja merupakan usaha dari suatu organisasi dalam suatu periode tertentu dan waktu tertentu untuk mengetahui keberhasilan dan kegagalan sebuah organisasi dalam melaksanakan kinerjanya. Kinerja keuangan yang dilihat berdasarkan dari laporan keuangan yang disajikan oleh manajemen akan memberi arti pada saat di analisis terhadap pelaksanaan kinerja yang dilakukan selama ini.

Menurut Suteja (2015, hlm. 66) laporan keuangan adalah laporan yang memuat hasil-hasil perhitungan dari proses akuntansi yang menunjukan kinerja keuangan suatu perusahaan pada suatu saat tertentu. Laporan keuangan yang disusun secara baik dan akurat dapat memberikan gambaran keadaan yang nyata mengenai hasil atau prestasi yang telah dicapai oleh suatu perusahaan selama kurun waktu tertentu yang digunakan untuk menilai kinerja keuangan. Namun laporan keuangan belum dapat dikatakan mencerminkan keadaan keuangan perusahaan secara keseluruhan. Dalam penerapannya, perusahaan tidak selalu dalam kondisi yang sesuai diharapkan dimana kondisi keuangan dalam keadaan baik, sering kali perusahaan mengalami kesulitan keuangan yang pada akhirnya jika tidak diatasi dengan tepat oleh pihak manajemen akan mengindikasikan terjadinya kebangkrutan. 
Kebangkrutan menurut Undang-Undang No. 4 tahun 1998 yaitu keadaan dimana suatu instutusi dinyatakan oleh keputusan pengadilan bila debitur memiliki dua atau lebih kreditur dan tidak membayar sedikitnya satu utang yang telah jatuh tempo dan dapat ditagih. Investor menghadapai risiko lebih tinggi, mengingat mereka mempunyai klaim residual, yaitu lebih akhir dari kreditor. Yang menjadi masalah biasanya adalah pada batas angka berapa dapat dikatakan bahwa perusahaan tersebut mengalami kebangkrutan. Untuk itulah diciptakan model dengan berbagai macam versinya. Salah satu model yang dapat digunakan dalam memprediksi kesulitan keuangan serta menganalisis perkembangan kinerja perusahaan ialah Altman Z Score. Altman dengan teorinya "Z Score Altman (1968)" menyatakan bahwa rasio keuangan sangat terbatas, karena rasio itu dihitung secara parsial. Altman menyajikan indeks dari berbagai variabel bebas untuk menentukan apakah suatu perusahaan itu akan bangkrut (tidak sehat) atau tidak bangkrut (sehat) (Utari dkk, 2014 hlm. 69). Berikut adalah model Z Score Modifikasi (1995):

$$
\begin{aligned}
& \text { Z” }=6.56 \mathrm{X} 1+3.26 \mathrm{X} 2+6.72 \mathrm{X} 3+2.05 \mathrm{X} 4 \\
& \begin{array}{l}
\text { Dimana: } \\
\text { Z }=\text { Index Keseluruhan } \\
\text { X1 }=\text { Working Capital to Total Asset } \\
\text { X2 }=\text { Retained Earning to Total Asset } \\
\text { X3 }=\text { Earning Before Interest and Taxes to Total Asset } \\
\text { X4 }=\text { Book Value of Equity to Book Value of Total Liabilities }
\end{array}
\end{aligned}
$$

Klasifikasi perusahaan model Altman modifikasi yaitu:

1. Jika nilai $Z<1.1$ maka termasuk perusahaan yang mengalami kebangkrutan.

2. Jika nilai $1.1<\mathrm{Z}<2.6$ maka termasuk grey area.

3. Jika nilai $Z>2.6$ maka termasuk perusahaan sehat.

Menurut Sukmawati dkk. (2014) Z Score dapat digunakan sebagai bahan untuk pertimbangan bagi investor dalam menganalisis perkembangan kinerja dan tingkat kesehatan perusahaan perusahaan emiten untuk menghindari terjadinya kesalahan investasi. Hal ini tentunya dapat mempengaruhi keputusan para pemegang saham dalam menanamkan modalnya di perusahaan. Sebab semakin banyak investor menanamkan modalnya di suatu perusahaan maka harga saham perusahaan tersebut semakin meningkat dimana sesuai dengan hukum ekonomi jika semakin tinggi permintaan akan saham maka harga saham akan naik (Noviarti, 2017).

\subsection{Working Capital To Total Asset dan Harga Saham}

Altman (1968) menyatakan bahwa rasio working capital to total asset (WCTA) sering kali dijumpai dalam studi kasus permasalahan perusahaan, ini adalah ukuran bersih pada aktiva lancar perusahaan terhadap modal perusahaan. Rasio working capital to total asset (WCTA) menunjukan kemampuan perusahaan untuk menghasilkan modal kerja bersih dari keseluruhan total aktiva yang dimilikinya. Menurut Noviarti (2017) jika rasio WCTA semakin rendah maka kemampuan perusahaan untuk memperoleh laba dan likuiditasnya menurun. Hal ini akan dihindari para investor untuk berinvestasi disaham perusahaan. Maka semakin rendah rasio WCTA dapat berakibat menurunnya minat para investor untuk membeli saham perusahaan. Turunnya minat investor terhadap saham perusahaan maka akan mengakibatkan turunnya permintaan harga saham perusahaan sehingga harga saham berpotensi turun. Oleh karena itu, WCTA memiliki hubungan positif terhadap harga saham. Hal ini didukung dengan penelitian yang dilakukan oleh Purwanda dan Yuniarti (2014) menyatakan bahwa working capital to total assets (WCTA) berpengaruh positif dan signifikan terhadap harga saham. 


\subsection{Retained Earning To Total Asset dan Harga Saham}

Altman (1968) menjelaskan bahwa rasio retained earning to total asset (RETA) adalah ukuran dari profitabilitas kumulatif dari waktu ke waktu sebagai salah satu rasio baru. Usia sebuah perusahaan secara implisit dipertimbangkan dalam rasio ini. Rasio ini menunjukan kemampuan perusahaan untuk menghasilkan laba di tahan dari aktiva perusahaan. Calon investor menilai profitabilitas perusahaan dari laba ditahan perusahaan, karena besarnya laba ditahan yang dimiliki perusahaan menjadi landasan calon investor untuk menanamkan sahamnya. Semakin besar laba ditahan tahun lalu akan semakin besar peminat terhadap saham perusahaan tersebut pada tahun ini yang menyebabkan harga saham naik (Purwanda dan Yuniarti, 2014). Oleh karena itu, RETA memiliki hubungan positif terhadap harga saham. Pernyataan tersebut didukung dengan penelitian terdahulu yang dilakukan oleh Adrian dan Khoiruddin (2014) yang menyatakan bahwa rasio retained earning to total asset (RETA) berpengaruh positif terhadap harga saham.

\subsection{Earning Before Interest and Tax To Total Asset dan Harga Saham}

Altman (1968) menyatakan bahwa rasio ini merupakan ukuran produktivitas dari aktiva perusahaan yang sesungguhnya terlepas dari pajak atau faktor leverage. Sejak keberadaan pokok perusahaan didasarkan pada kemampuan menghasilkan laba dari aktiva-aktivanya, rasio ini muncul menjadi yang paling utama sesuai untuk studi yang berhubungan dengan kegagalan perusahaan. Rasio ini menunjukan kemampuan perusahaan untuk menghasilkan laba dari aktiva perusahaan sebelum pembayaran bunga dan pajak atau laba operasi. Jika rasio EBIT/TA turun hal ini akan membuat minat investor terhadap saham perusahaan turun kemudian mengakibatkan turunnya permintaan akan saham perusahaan sehingga harga saham berpotensi turun (Noviarti 2017). Hal ini menunjukan bahwa EBIT/TA berpengaruh terhadap harga saham yang didukung oleh penelitian yang dilakukan Sukmawati dkk. (2014) yang menyatakan bahwa variabel EBIT/TA berpengaruh positif dan signifikan terhadap harga saham.

\subsection{Book Value of Equity To Book Value of Total Liabilities dan Harga Saham}

Altman (1983) menyatakan bahwa rasio ini mengukur seberapa jauh nilai buku ekuitas perusahaan akan menurun sebelum kewajiban melebihi asset perusahaan. Investor membutuhkan informasi mengenai kesehatan perusahaan melalu perbandingan antara modal sendiri dan modal pinjaman. Perusahaan yang memiliki modal sendiri yang lebih besar daripada modal pinjaman berarti sehat dan tidak mudah bangkrut. Oleh karena itu investor harus selalu mengikuti perkembangan rasio ekuitas terhadap utang (Samsul, 2015 hlm. 219). Semakin produktif suatu perusahaan maka semakin besar return saham yang diberikan kepada investor, semakin besar return yang diberikan maka semakin meningkat harga saham. Hal ini menunjukan bahwa rasio book value of equity to book value of total liabilities berpengaruh terhadap harga saham.

\subsection{Kerangka Pemikiran}




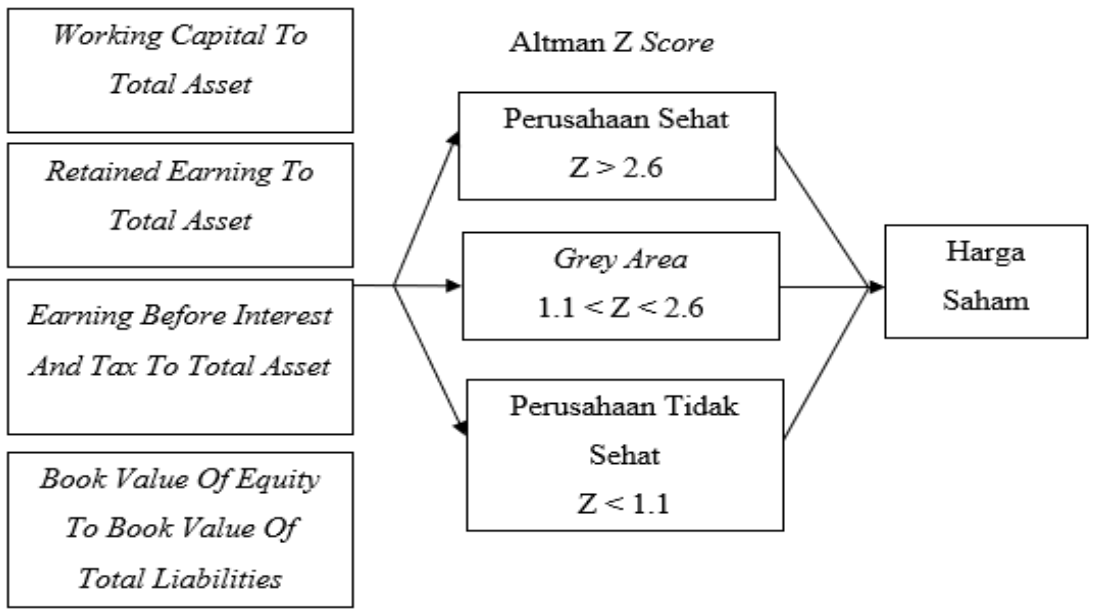

\subsection{Hipotesis}

Pengembangan hipotesis yang ada pada penelitian ini berdasarkan identifikasi masalah serta kerangka pemikiran yang ada adalah sebagai berikut:

H1: Working Capital To Total Assets (WCTA) berpengaruh signifikan terhadap Harga Saham

H2: Retained Earning To Total Asset (RETA) berpengaruh signifikan terhadap Harga Saham

H3: Earning Before Interest And Tax To Total Asset (EBITA) berpengaruh signifikan terhadap Harga Saham

H4: Book Value Of Equity To Book Value Of Total Liabilities (BVEBVTL) berpengaruh signifikan terhadap Harga Saham

H5: Altman Z Score berpengaruh signifikan terhadap Harga Saham

\section{METODE PENELITIAN}

\subsection{Populasi dan Sampel}

Populasi dalam penelitian ini adalah seluruh perusahaan industri barang konsumsi yang terdaftar pada Bursa Efek Indonesia (BEI) tahun 2016-2017 dengan penentuan sampel menggunakan teknik puposive sampling.

\subsection{Pengukuran Variabel}

\section{Variabel Dependen}

Harga Saham (Y) merupakan nilai dari suatu saham yang mencerminkan kekayaan perusahaan yang mengeluarkan saham tersebut. Harga saham yang digunakan dalam penelitian ini yaitu harga saham penutupan (closing price) dengan menggunakan harga saham rata-rata pertahun

\section{Variabel Independen}

a. Working Capital to Total Asset $\left(\mathrm{X}_{1}\right)$

Working capital to total asset merupakan kemampuan perusahaan untuk memenuhi kewajiban jangka pendeknya. Rasio ini dirumuskan sebagai berikut:

$$
X 1=\frac{\text { Current Asset }- \text { Current Liabilies }}{\text { Total Asset }}
$$

b. Retained Earning to Total Asset $\left(\mathrm{X}_{2}\right)$

Retained earning to total asset merupakan kemampuan perusahaan apakah laba kumulatif perusahaan dapat mengimbangi jumlah aset perusahaan. Rasio ini dirumuskan sebagai berikut: 


$$
X 2=\frac{\text { Retained Earning }}{\text { Total Asset }}
$$

c. Earning Before Interest and Taxes to Total Asset $\left(\mathrm{X}_{3}\right)$

Earning before interest and taxes to total asset merupakan ukuran perusahaan dari produktivitas sebenarnya terhadap aktiva perusahaan. Rasio ini dirumuskan sebagai berikut:

$$
X 3=\frac{E B I T}{\text { Total Asset }}
$$

d. Book Value of Equity to Book Value of Total Liabilities $\left(\mathrm{X}_{4}\right)$

Book value of equity to book value of total liabilities merupakan ukuran beban utang yang ditangung perusahaan dibandingkan dengan ekuitasnya. Rasio ini dirumuskan sebagai berikut:

$$
. X 4=\frac{\text { Book Value of Equity }}{\text { Book Value of Total Liabilities }}
$$

\subsection{Teknik Analisis Data Altman Z Score}

Dari data laporan keuangan perusahaan akan dianalissis dengan menggunakan beberapa rasio keuangan yang dianggap dapat menilai kinerja keuangan perusahaan. Beberapa rasio keuangan yang mendeteksi likuiditas, profitabilitas, dan aktivitas perusahaan akan menghasilkan rasio atau angka yang selanjutnya diproses dengan menggunakan rumus Altman. Hasil perhitungan kemudian akan dianalisis dengan menggunakan sebuah formula yang ditemukan Altman. Rasio keuangan yang dianalisis adalah rasio-rasio yang berkaitan dengan model Altman. Teknik analisis Altman berawal dari data-data yang diolah kemudian akan dihitung dengan nilai Altman Z Score dengan rumus sebagai berikut:

$$
Z=6.55 X 1+3.62 \times 2+6.72 \times 3+1.05 X 4
$$

Dimana :

$$
\begin{array}{ll}
\mathrm{Z} & =\text { Index Keseluruhan } \\
\mathrm{X} 1 & =\text { Working Capitan to Total Asset } \\
\mathrm{X} 2 & \text { = Retained Earning to Total Asset } \\
\mathrm{X} 3 & \text { = Earning Before Interest and Taxes to Total Asset } \\
\mathrm{X} 4 & \text { = Book Value of Equity to Book Value of Total Liabilities }
\end{array}
$$

Klasifikasi perusahaan yang sehat dan bangkrut didasarkan pada nilai Z Score model Altman modifikasi yaitu:

a. Jika nilai $\mathrm{Z}<1.1$ maka dikategorikan sebagai perusahaan tidak sehat yang memiliki kesulitan keuangan dan beresiko tinggi sehingga kemungkinan terjadinya kebangkrutan sangat besar.

b. Jika nilai $1.1<\mathrm{Z}<2.6$ maka dikategorikan berada di grey area sehingga dikategorikan sebagai perusahaan yang memiliki kesulitan keuangan, namun kemungkinan terselamatkan dan kemungkinan bangkrut sama besarnya tergantung pihak manajemen perusahaan mengambil tindakan.

c. Jika nilai $Z>2.6$ maka dikategorikan sebagai perusahaan yang sehat sehingga tidak mengalami kesulitan keuangan.

\subsection{Model Regresi}

Model regresi yang digunakan penelitian ini yaitu analisis linier berganda dengan bantuan program Microsoft Excel 2017 dan IBM SPSS 23. Berikut adalah model regresi berganda:

$$
\begin{aligned}
& Y=a+b_{1} X_{1}+b_{2} X_{2}+b_{3} X_{3}+b_{4} X_{4}+b_{5} X_{5}+e \\
& \text { Keterangan : } \\
& Y \quad=\text { Harga Saham }
\end{aligned}
$$




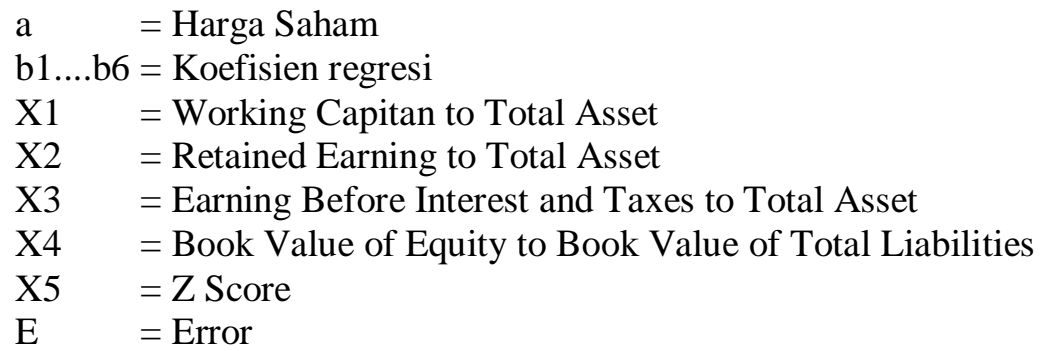

\section{HASIL DAN PEMBAHASAN}

\subsection{Deskripsi Obyek Penelitian}

Obyek penelitian yang digunakan dalam penelitian ini adalah perusahaan industri barang konsumsi di Bursa Efek Indonesia (BEI). Berdasarkan informasi dari www.idx.co.id jumlah perusahaan industri barang konsumsi di BEI berjumlah 46 perusahaan, yang memenuhi kriteria sampel 36 perusahaan dengan periode pengamatan 2 tahun sehingga sampel data menjadi 72 sampel.

\subsection{Teknik Analisis dan Uji Hipotesis Statistik Deskriptif}

Tabel 2. Hasil Statistik Deskriptif

\begin{tabular}{lccccc}
\hline \multicolumn{5}{c}{ Descriptive Statistics } \\
\hline WCTA & $\mathrm{N}$ & Minimum & Maximum & Mean & Std.Deviation \\
\hline RETA & 72 & -.2562 & .7971 & .320096 & .2289375 \\
\hline EBITA & 72 & -.4476 & .8245 & .291203 & .2907254 \\
\hline BVEBVTL & 72 & -.1109 & .7091 & .125308 & .1488596 \\
\hline ZSCORE & 72 & .2022 & 12.0049 & 2.322586 & 2.0899524 \\
\hline HS & 72 & 0 & 2 & 1.76 & .544 \\
\hline Valid N (listwise) & 72 & 4.3810 & 11.1718 & 7.200785 & 1.8046260 \\
\hline
\end{tabular}

Sumber: Data Olah SPSS

a. Variabel Working Capital To Total Asset (WCTA) dari 72 sampel perusahaan Industri Barang Konsumsi tahun 2016-2017 dengan nilai rata-rata (mean) WCTA sebesar 0.320096 dengan nilai standar deviasi sebesar 0.2289375 , dimana nilai standar deviasi yang besar (lebih dari 30\% dari Mean) menunjukan adanya kesenjangan yang besar dari WCTA terendah dan WCTA tertinggi. Nilai maximum variabel WCTA sebesar 0.7971 diwakili oleh PT.Delta Djakarta Tbk tahun 2017. Nilai ini menunjukan bahwa perusahaan baik dalam pengelolaan modal kerja bersihnya dikarenakan nilai WCTA lebih besar dari rata-rata sebesar 0.320096. Dan pada nilai minimum variabel WCTA sebesar -0.2562 yang diwakili oleh PT.Unilever Indonesia Tbk tahun 2016. Nilai ini menunjukan bahwa perusahan belum dapat mengelola modal kerja bersihnya dengan baik sebab utang lancar melebihi aset lancar perusahaan dikarenakan nilai WCTA lebih kecil dari rata-rata sebesar 0.320096.

b. Variabel Retained Earning To Total Asset (RETA) dari 72 sampel perusahaan Industri Barang Konsumsi tahun 2016-2017 dengan rata-rata sebesar 0.291203 dengan standar deviasi sebesar 0.2907254. Standar deviasi yang besar (lebih dari 30\% dari Mean) menunjukan adanya kesenjangan yang besar dari RETA terendah dan RETA tertinggi. Nilai maksimum variabel RETA adalah 0.8245 diwakili PT.Delta Djakarta Tbk tahun 2017. Nilai ini menunjukan perusahaan memperoleh laba ditahan dengan memaksimalkan jumlah aset perusahaan dikarenakan nilai RETA lebih besar dari rata-rata sebesar 0.291203. Dan nilai minimum 
variabel RETA adalah -0.4476 diwakili PT.Bantoel Internasional Investama Tbk tahun 2017. Nilai ini menunjukan bahwa perusahaan belum dapat memaksimalkan aset perusahaan dalam memperoleh laba ditahan dikarenakan nilai RETA lebih kecil dari nilai rata-rata 0. 291203.

c. Variabel Earning Before Interest And Tax To Total Asset (EBITA) dari 72 sampel perusahaan Industri Barang Konsumsi tahun 2016-2017 dengan rata-rata (mean) sebesar 0.125308 dengan nilai standar deviasi sebesar 0.14885960. Standar deviasi yang besar (lebih dari 30\% dari Mean) menunjukan adanya kesenjangan yang besar dari EBITA terendah dan EBITA tertinggi. Nilai maksimum variabel EBITA sebesar 0.7091 oleh PT.Multi Bintang Indonesia Tbk tahun 2017. Nilai ini menunjukan bahwa perusahaan sudah memaksimalkan aset perusahaan yang dimiliki sehingga menghasilkan laba usaha yang maksimal ditunjukan dari nilai EBITA perusahaan lebih besar dari nilai rata-rata sebesar 0.125308. Dan nilai minimum variabel EBITA sebesar -0.1109 oleh PT.Tiga Pilar Sejahtera Food Tbk tahun 2017. Nilai ini menunjukan bahwa perusahaan belum secara maksimal menghasilkan laba usaha dari aktivitas perusahaan dikarenakan nilai variabel EBITA masih di bawah dari rata-rata sebesar 0.125308.

d. Variabel Book Value Of Equity To Book Value Of Total Liabilities (BVEBVTL) dari 72 sampel perusahaan Industri Barang Konsumsi tahun 2016-2017 dengan rata-rata (mean) sebesar sebesar 2.322586 dengan standar deviasi sebesar 2.0899524. Standar deviasi yang besar (lebih dari 30\% dari Mean) menunjukan adanya kesenjangan yang besar dari BVEBVTL terendah dan BVEBVTL tertinggi. Nilai maksimum variabel BVEBVTL sebesar 12.0049 oleh PT.Industri Jamu dan Farmasi Sido Muncul Tbk tahun 2016. Nilai ini mecerminkan sebagian besar modal perusahaan diperoleh dari modal sendiri (ekuitas berupa saham) jika dibandingkan modal pinjaman dikarenakan nilai BVEBVTL lebih besar dari nilai rata-rata 2.322586. Dan nilai minimum variabel BVEBVTL sebesar 0.2022 oleh PT.Merck Sharp Dohme Pharma Tbk tahun 2016 . Nilai ini mencerminkan sebagian besar modal perusahaan berasal dari modal pinjaman jika dibandingkan dengan modal sendiri (ekuitas berupa saham serta didukung dari nilai BVEBVTL yang lebih kecil dari rata-rata industri sebesar 2.322586.

e. Variabel Z Score dari 72 sampel perusahaan Industri Barang Konsumsi tahun 2016-2017 dengan nilai rata-rata (mean) sebesar 1.76 dengan nilai standar deviasi sebesar 0.544. Standar deviasi yang besar (lebih dari 30\% dari Mean) menunjukan adanya kesenjangan yang besar dari Z Score terendah dan Z Score tertinggi. Nilai Z Score minimum sebesar 0 sebanyak 4 perusahaan diwakili PT.Tri Bayan Tirta Tbk. Dan nilai Z Score maksimum sebesar 2 sebanyak 59 perusahaan diwakili PT.Industri Jamu dan Farmasi Sido Muncul Tbk.

f. Variabel Harga saham (HS) dari 72 sampel perusahaan Industri Barang Konsumsi tahun 20162017 dengan perolehan nilai rata-rata (mean) sebesar sebesar 7.400785 dengan nilai standar deviasi atau simpangan baku sebesar1.8046260. Standar deviasi yang cukup besar (lebih dari 20\% dari Mean) menunjukan adanya variasi atau kesenjangan yang cukup besar dari HS terendah dan HS tertinggi. Nilai maksimum variabel HS sebesar 11.1718 diwakili oleh PT.Gudang Garam Tbk tahun 2017. Dan nilai minimum variabel HS sebesar 4.3810 oleh PT.Budi Starch \& Sweetener Tbk tahun 2016.

Tabel 10. Hasil Korelasi

\begin{tabular}{|c|c|c|c|}
\hline \multicolumn{4}{|c|}{ Coefficients $^{a}$} \\
\hline & Model & $\mathrm{t}$ & Sig. \\
\hline \multirow{6}{*}{1} & (Constant) & 10.308 & .000 \\
\hline & WCTA & .463 & .645 \\
\hline & RETA & 2.440 & .017 \\
\hline & EBITA & 4.726 & .000 \\
\hline & BVEBVTL & -2.615 & .011 \\
\hline & ZSCORE & 1.537 & .129 \\
\hline
\end{tabular}

EQUITY: Jurnal Ekonomi, Manajemen, Akuntansi | Vol. 22, No. 1 


\begin{tabular}{l}
\hline a. Predictors: (Constant), ZSCORE, BVEBVTL, EBITA, RETA, \\
WCTA \\
\hline b. Dependent Variable: HS
\end{tabular}

Sumber: Data Olah SPSS

a. Working Capital To Total Assets (WCTA) dengan probabilitas $0.645>0.05$ dan $\mathrm{t}_{\text {hitung }}<\mathrm{t}_{\text {tabel }}$ yaitu $0.463<1.996$ berarti $\mathrm{H}_{0}$ diterima. Working Capital To Total Assets (WCTA) tidak berpengaruh signifikan terhadap Harga Saham.

b. Retained Earning To Total Asset (RETA) dengan probabilitas $0.017<0.05$ dan $\mathrm{t}_{\text {hitung }}>\mathrm{t}_{\text {tabel }}$ yaitu $2.440>1.996$ berarti $\mathrm{H}_{2}$ diterima. Retained Earning To Total Asset (RETA) berpengaruh signifikan terhadap Harga Saham.

c. Earning Before Interest and Tax To Total Asset (EBITA) dengan probabilitas $0.000<0.05$ dan $\mathrm{t}_{\text {hitung }}>\mathrm{t}_{\text {tabel }}$ yaitu $4.726>1.996$ berarti $\mathrm{H}_{3}$ diterima. Earning Before Interest and Tax To Total Asset (EBITA) berpengaruh signifikan terhadap Harga Saham.

d. Book Value of Equity To Book Value of Total Liabilities (BVEBVTL) dengan probabilitas $0.011<0.05$ dan $\mathrm{t}_{\text {hitung }}>\mathrm{t}_{\text {tabel }}$ yaitu $2.615>1.996$ berarti $\mathrm{H}_{4}$ diterima. Book Value of Equity To Book Value of Total Liabilities (BVEBVTL) berpengaruh signifikan negatif terhadap Harga Saham.

e. Z Score dengan probabilitas $0.129>0.05$ dan $\mathrm{t}_{\text {hitung }}<\mathrm{t}_{\text {tabel }}$ yaitu $1.537<1.996$ berarti $\mathrm{H}_{0}$ diterima. Z Score tidak berpengaruh signifikan terhadap Harga Saham.

Uji Model Regresi Linier Berganda

Tabel 11. Hasil Uji Regresi Linier Berganda

\begin{tabular}{|c|c|c|c|c|c|c|}
\hline \multicolumn{7}{|c|}{ Coefficients $^{a}$} \\
\hline \multirow[t]{2}{*}{ Mode } & & \multicolumn{2}{|c|}{$\begin{array}{l}\text { Unstandardized } \\
\text { Coefficients }\end{array}$} & \multirow{2}{*}{$\begin{array}{c}\text { Standardized } \\
\text { Coefficients } \\
\text { Beta }\end{array}$} & \multirow{2}{*}{$\mathrm{t}$} & \multirow{2}{*}{ Sig. } \\
\hline & & B & Std. Error & & & \\
\hline \multirow[t]{6}{*}{1} & (Constant) & 5.520 & .536 & & 10.308 & .000 \\
\hline & WCTA & .455 & .983 & .058 & .463 & .645 \\
\hline & RETA & 1.655 & .678 & .267 & 2.440 & .017 \\
\hline & EBITA & 6.178 & 1.307 & .510 & 4.726 & .000 \\
\hline & BVEBVTL & -.236 & .090 & -.273 & -2.615 & .011 \\
\hline & ZSCORE & .582 & .379 & .175 & 1.537 & .129 \\
\hline
\end{tabular}

a. Dependent Variable: HS

Sumber: Data Olah SPSS

Dari tabel di atas, maka diperoleh persamaaan regresi sebagai berikut:

$\mathrm{HS}=5.520+0.455 \mathrm{WCTA}+1.655$ RETA + 6.178 EBITA $-0.236 \mathrm{BVEBVTL}+0.582 \mathrm{ZSCORE}$

Dari persamaan regresi di atas dapat diartikan bahwa nilai konstanta 5.520 menunjukan ketika seluruh variabel independen yaitu WCTA, RETA, EBITA, BVEBVTL, dan Z Score mengalami nilai konstan atau 0 maka, variabel dependen yaitu Harga Saham akan bernilai sebesar 5.520 .

Variabel Working Capital To Total Assets (WCTA) dengan koefisien 0.455 menyatakan apabila variabel Working Capital To Total Assets (WCTA) mengalami kenaikan satu satuan (dengan asumsi bahwa nilai koefisien variabel lain tetap), maka kemungkinan Harga Saham mengalami kenaikan sebesar 0.455 .

Variabel Retained Earning To Total Asset (RETA) dengan koefisien sebesar 1.655 menyatakan apabila variabel Retained Earning To Total Asset (RETA) mengalami kenaikan satu 
satuan (dengan asumsi bahwa nilai koefisien variabel lain tetap), maka kemungkinan Harga Saham mengalami kenaikan sebesar 1.655.

Variabel Earning Before Interest and Tax To Total Asset (EBITA) dengan koefisien sebesar 6.178 menyatakan apabila variabel Earning Before Interest and Tax To Total Asset (EBITA) mengalami kenaikan satu satuan (dengan asumsi bahwa nilai koefisien variabel lain tetap), maka kemungkinan Harga Saham mengalami kenaikan sebesar 6.178.

Variabel Book Value of Equity To Book Value of Total Liabilities (BVEBVTL) dengan koefisien negatif sebesar -0.236 menyatakan variabel Book Value of Equity To Book Value of Total Liabilities (BVEBVTL) mengalami penurunan satu satuan (dengan asumsi bahwa nilai koefisien variabel lain tetap) maka kemungkinan Harga Saham mengalami penurunan sebesar 0.236 .

Variabel Z Score dengan koefisien sebesar 0.582 menyatakan variabel Z Score mengalami kenaikan satu satuan (dengan asumsi bahwa nilai koefisien variabel lain tetap) maka kemungkinan Harga Saham mengalami kenaikan sebesar 0.582.

\subsection{HASIL DAN PEMBAHASAN}

Berdasarkan penelitian yang telah dilakukan dari 36 sampel perusahaan dengan periode penelitian 2 tahun, bahwa hanya 17 sampel perusahaan dimana 12 sampel perusahaan menunjukan kenaikan rasio working capital to total asset dengan kenaikan harga saham, dan 5 sampel perusahaan menunjukan penurunan rasio working capital to total asset dengan penurunan harga saham. 19 sampel perusahaan lainnya tidak menunjukan hubungan yang searah antara working capital to total assets dengan harga saham. Hal ini membuktikan bahwa dalam penelitian ini hanya sedikit sampel yang menunjukan adanya pengaruh antara working capital to total asset harga saham. Tidak adanya pengaruh Working Capital To Total Asset (WCTA) terhadap harga saham dapat dikarenakan perputaran modal kerja bersih perusahaan yang bersifat jangka pendek sedangkan saham ialah bentuk penyertaan kepemilikan jangka panjang. Selain itu sebagian besar investor spekulan yang berinvestasi jangka pendek dalam bentuk instrumen surat berharga di pasar modal sehingga tidak melihat rasio working capital to total assets lebih memilih rasio keuangan yang lain atau faktor lain dalam pertimbangan pembelian saham. Hasil penelitian ini didukung oleh penelitian terdahulu dilakukan Noviarti (2017) dan Sukmawati, dkk. (2014) yang menyatakan bahwa rasio working capital to total assets tidak berpengaruh terhadap harga saham

Adanya pengaruh Retained Earning To Total Asset (RETA) terhadap harga saham dalam penelitian ini dikarenakan investor menilai bahwa profitabilias perusahaan yang dilihat dari laba ditahan yang dihasilkan perusahaan karena besarnya laba ditahan yang dimiliki perusahaan menjadi landasan investor dalam menanamkan sahamnya. Semakin besar laba ditahan tahun lalu akan semakin besar peminat terhadap saham perusahaan tersebut yang menyebabkan harga saham naik. Sebab laba maksimal perusahaan adalah cerminan dari kinerja yang baik yang ditunjukan dari laba perusahaan yang dapat menjadi landasan investor untuk membeli sahamnya diperusahaan tersebut. Hasil penelitian ini didukung oleh penelitian terdahulu yang dilakukan oleh Purwanda dan Yuniarti (2014) dan Adrian dan Khiruddin (2014) yang menyatakan bahwa rasio retained earning to total asset berpengaruh positif terhadap harga saham.

Adanya pengaruh Earning Before Interest and Tax To Total Asset (EBITA) terhadap harga saham dikarenakan rasio EBITA yang tinggi menunjukan bahwa manajemen mampu dalam mengelola aset perusahaan dengan baik sehingga sehingga perusahaan memperoleh laba yang tinggi yang tentunya menjadi pertimbangan bagi investor untuk berinvestasi, sehingga akan berdampak pada harga saham perusahaan. Laba maksimal yang dihasilkan perusahaan adalah cerminan kemampuan kinerja manajemen yang ditunjukan dari laba perusahaan. Hasil penelitian

EQUITY: Jurnal Ekonomi, Manajemen, Akuntansi | Vol. 22, No. 1 
ini didukung oleh penelitian terdahulu yang dilakukan oleh Sukmawati dkk. (2014) dan Adrian dan Khoiruddin (2014) yang menyatakan bahwa rasio EBITA berpengaruh positif terhadap harga saham.

Penelitian ini berhasil membuktikan bahwa harga saham dipengaruhi oleh Book Value of Equity To Book Value of Total Liabilities. Peningkatan rasio BVEBVTL diikuti dengan kenaikan harga saham dan rendahnya rasio BVEBVTL diikuti dengan penurunan harga saham. Jika utang perusahaan yang terlampau besar melebihi ekuitas perusahaan maka akan berbahaya bagi kelangsungan perusahaan karena ekuitas yang perusahaan miliki belum tentu dapat mengcover utang perusahaan yang terlampau besar, terutama apabila terdapat bunga yang harus dibayar. Hal ini mencerminkan bahwa perusahaan belum dapat dikatakan produktif dalam menjalankan aktivitasnya yang tentunya akan menurunkan return saham yang diberikan kepada investor, semakin rendah return yang diberikan yang akan menyebabkan menurunnya permintaan dan penurunan harga saham. Hasil penelitian ini didukung oleh penelitian terdahulu oleh Syamni dkk (2018) menyatakan bahwa rasio-rasio Altman yang salah satunya yaitu book value of equity to book value of total liabilities memiliki pengaruh terhadap harga saham.

Penelitian ini membuktikan bahwa harga saham tidak dipengaruhi oleh Z Score. Tidak adanya pengaruh Z Score terhadap harga saham dapat dilihat dari nilai koefisien dererminasi $\left(\mathrm{R}^{2}\right)$ sebesar 0.493 atau $49.3 \%$. Nilai tersebut menunjukan presentase pengaruh variabel independen (Z Score) terhadap variabel dependen (harga saham) sebesar 49.3\%, sisanya yaitu sebesar $50.7 \%$ dipengaruhi oleh faktor dan variabel lain yang tidak dimasukan kedalam penelitian ini atau faktor lain yang lebih dominan. Selain itu tidak adanya pengaruh Z Score terhadap harga saham disebabkan karena harga saham tidak mencerminkan kondisi perusahaan yang sesungguhnya sebab tidak semua variabel memiliki keterkaitan dan dapat dijadikan sebagai satu-satunya dasar dalam menentukan harga saham. Hal ini menunjukan bahwa masih banyak faktor-faktor lain yang mendukung pergerakan harga saham perusahaan. Oleh karena itu, investor dapat melihat dari beberapa aspek dalam penilaiannya terhadap harga saham perusahaan. Hasil penelitian ini didukung oleh penelitian terdahulu oleh Ardian dan Khoiruddin (2014) dan Marcelina (2014) yang menyatakan bahwa Z Score tidak memiliki pengaruh yang signifikan terhadap harga saham.

\section{SIMPULAN, KETERBATASAN DAN SARAN}

\subsection{Simpulan}

Berdasarkan hasil penelitian yang telah dilakukan serta pembahasan yang telah diuraikan diatas, maka dapat diambil kesimpulan sebagai berikut

a. Hasil nilai Z Score dari 72 sampel perusahaan yang terdaftar pada Bursa Efek Indonesia (BEI) tahun 2016-2017 diketahui 4 perusahaan dalam kategori tidak sehat, 9 perusahaan dalam ketegori grey area (kurang sehat), dan 59 perusahaan dalam kategori sehat.

b. Hasil uji signifikansi parameter individual (uji t) menunjukan bahwa variabel RETA, EBITA, dan BVEBVTL mempunyai angka signifikan dibawah 0.05 dan $t_{\text {hitung }}>t_{\text {tabel }}$ artinya ketiga variabel independen tersebut mempengaruhi harga saham sedangkan variabel WCTA dan Z Score mempunyai angka signifikan diatas 0.05 dan $t_{\text {hitung }}<t_{\text {tabel }}$ artinya kedua variabel independen tersebut tidak mempengaruhi harga saham.

\subsection{Keterbatasan}

Secara garis besar keterbatasan penelitian ini antara lain periode waktu penelitian hanya 2 tahun, sample penelitian dibatasi hanya perusahaan manufaktur di bidang industri barang 
konsumsi, dan akan lebih maksimal apabila periode penelitian ini lebih dari 3 tahun serta sampel yang digunakan seluruh perusahaan manufaktur yang terdaftar di Bursa Efek Indonesia.

\subsection{SARAN}

a. Bagi Perusahaan

Untuk mengamati naik turunnya harga saham sebaiknya perusahaan juga perlu mengamati variabel variabel yang digunakan dalam analisis Almant $\mathrm{Z}$ score

b. Bagi Investor

Bagi para investor harus cermat dalam mengawasi perkembangan kondisi internal perusahaan dengan tidak mengabaikan faktor eksternal perusahaan. Sehingga tujuan utama perusahaan untuk meningkatkan dengan menggunakan analisis Altman $\mathrm{Z}$ Score dapat tercapai

\section{DAFTAR PUSTAKA}

Adrian, A. dan Moh K. (2014). Pengaruh Analisis Kebangkrutan Model Altman Terhadap Harga Saham Perusahaan Manufaktur.

Andriawan, N.F dan Dantje S. (2016). Analisis Metode Altman Z-Score Sebagai Alat Prediksi Kebangkrutan dan Pengaruhnya Terhadap Harga Saham Pada Perusahaan Farmasi Yang Terdaftar Di Bursa Efek Indonesia.

Altman, Edward I. (1968). Financial Ratios, Discriminant Analysis and the Prediction of Corporate Bankcruptcy. Journal of Finance, 23, No. 4: 589-609.

Fahmi, I. (2015). Manajemen Investasi Teori dan Soal Jawab. Jakarta: Salemba Empat.

Fahmi, I. (2008). Analisis Kredit dan Fraud Pendekatan Kualitatid dan Kuantitatif. Jakarta: P.T. Alumni.

Ghozali, I. (2016). Aplikasi Analisis Multivariate dengan Program IBM SPSS 23. Semarang: Badan Penerbit Universitas Diponegoro.

Hartono, J. (2015). Teori Portofolio dan Analisis Investasi Edisi Kesepuluh. Yogyakarta: BPFEYogyakarta.

Hery. (2016). Analisis Laporan Keuangan. Jakarta: PT Grasindo.

Houston, dan Brigham. (2006). Dasar-Dasar Manajemen Keuangan Edisi 10 Buku 1. Jakarta: Salemba Empat.

Ikatan Akuntansi Indonesia. (2017). Standar Akuntansi Keuangan 2017.

Jainur, S.J, dkk. (2016). Pengaruh Altman Z-Score Terhadap Harga Saham.

Kementrian Perindustrian. Analiisis Perkembangan Industri 2017.

Kompas (2018). Konsumsi Rumah Tangga Sumbang Separuh Struktur Ekonomi. Diakses 4 September 2018, dari

EQUITY: Jurnal Ekonomi, Manajemen, Akuntansi | Vol. 22, No. 1 186 DOI: 10.34209/equ.v22i1.924 
https://ekonomi.kompas.com/read/2018/02/05/130300426/konsumsi-rumah-tanggasumbang-separuh-struktur-ekonomi-indonesia

Mercelina, T. A. (2014). Prediksi Kebangkrutan Menggunakan Metode Z-Score Dan Pengaruhnya Terhadap Harga Saham Pada Perusahaan Transportasi yang Terdaftar DI Bursa Efek Indonesia Tahun 2008-2012.

Noviarti. (2017). Pengaruh Kebangkrutan Model Altman Z-Score Terhadap Harga Saham Perusahaan Manufaktur Yang Terdapat Di BEI Periode 2014-2016.

Purwanda, E. dan Kristin Y. (2014). Pengujian Dampak Rasio Altman, DER, dan Tingkat Suku Bunga Terhadap Harga Saham Perusahaan Sektor Pertambangan Di Bursa Efek Indonesia.

Samsul, M. (2015). Pasar Modal dan Manajemen Portofolio Edisi 2. Jakarta: Penerbit Erlangga.

Sanobaranjum. (2012). Business Bankrupty Predicition Models: A Significant Study of The Altman's Z-Score Model.

Sitanggang, J.P. (2013). Manajemen Keuangan Perusahaan Lanjutan. Jakarta: Mitra Wacana Media

Sitanggang, J.P. (2014). Manajemen Keuangan Perusahaan Edisi 2. Jakarta: Mitra Wacana Media

Sukmawati, dkk. (2014). Pengaruh Rasio-Rasio Dalam Model Altman Z Score Terhadapp Harga Saham.

Suteja, I.G.N. (2018). Analisis Kinerja Keuangan dengan Metode Altman Z-Score Pada PT ACE Hardware Indonesia Tbk.

Syamni, G. dkk. (2018). Bankruptcy Prediction Model and Stock Prices of the Coal Mining Industry in Indonesia.

CNBC Indonesia. Pertumbuhan Indsutri Barang Konsumsi Dinilai Melambat. Diakses pada 31 Oktober 2018.

https://www.cnbcindonesia.com/market/20181019191302-17-8252/pertumbuhanindustri-barang-konsumsi-dinilai-melambat

CNBC Indonesia. Saham Barang Konsumsi Akan Terpengaruh Pelemahan Penjualan. Diakses pada 1 November 2018.

https://www.cnbcindonesia.com/market/20180207190732-17-3829/saham-barang-

konsumsi-akan-terpengaruh-pelemahan-penjualan

CNNI Indonesia. Wases Awan Hitam Deindustrilisasi. Diakses pada 1 November 2018.

https://www.cnnindonesia.com/ekonomi/20171108103721-92-254249/waswas-awanhitam-deindustrialisasi

Undang-Undang No. 8 tahun 1995. Pasar Modal.

EQUITY: Jurnal Ekonomi, Manajemen, Akuntansi | Vol. 22, No. 1 
Undang-Undang No. 4 tahun 1998. Kepailitan

EQUITY: Jurnal Ekonomi, Manajemen, Akuntansi | Vol. 22, No. 1 DOI: 10.34209/equ.v22i1.924 
